\title{
Therapeutic Role of Nystatin Added to Tissue Conditioners for Treating Denture-Induced Stomatitis: A Systematic Review
}

\author{
Muhammad Saad Shaikh ${ }^{1}(\mathbb{D})$, Ahmad Alnazzawi ${ }^{2}\left(\mathbb{D}\right.$, Syed Rashid Habib $^{3}\left(\mathbb{D}\right.$, Mohid Abrar Lone $^{4}$ \\ and Muhammad Sohail Zafar ${ }^{5,6, * \text { D }}$
}

check for

updates

Citation: Shaikh, M.S.; Alnazzawi, A.; Habib, S.R.; Lone, M.A.; Zafar, M.S. Therapeutic Role of Nystatin Added to Tissue Conditioners for Treating Denture-Induced Stomatitis: A Systematic Review. Prosthesis 2021, 3, 61-74. https://doi.org/10.3390/ prosthesis 3010007

Received: 28 December 2020

Accepted: 29 January 2021

Published: 3 February 2021

Publisher's Note: MDPI stays neutral with regard to jurisdictional claims in published maps and institutional affiliations.

Copyright: (c) 2021 by the authors. Licensee MDPI, Basel, Switzerland. This article is an open access article distributed under the terms and conditions of the Creative Commons Attribution (CC BY) license (https:// creativecommons.org/licenses/by/ $4.0 /)$.
1 Department of Oral Biology, Sindh Institute of Oral Health Sciences, Jinnah Sindh Medical University, Karachi 75510, Pakistan; drsaadtanvir@gmail.com

2 Department of Substitutive Dental Sciences, College of Dentistry, Taibah University, Al Madinah, Al Munawwarah 41311, Saudi Arabia; alnazzawi@gmail.com

3 Department of Prosthetic Dental Sciences, College of Dentistry, King Saud University, Riyadh 11545, Saudi Arabia; syhabib@ksu.edu.sa

4 Department of Oral Pathology, Sindh Institute of Oral Health Sciences, Jinnah Sindh Medical University, Karachi 75510, Pakistan; mohid.lone@jsmu.edu.pk

5 Department of Restorative Dentistry, College of Dentistry, Taibah University, Al Madinah, Al Munawwarah 41311, Saudi Arabia

6 Department of Dental Materials, Islamic International Dental College, Riphah International University, Islamabad 44000, Pakistan

* Correspondence: MZAFAR@taibahu.edu.sa; Tel.: +966-507544691

\begin{abstract}
Denture-induced stomatitis (DIS) represents a pathological condition caused by ill-fitting dentures trauma, manifested as inflammation of the palatal tissue beneath the denture. The fungal infections are the principal contributory factors to DIS. Although the aetiology of DIS is multifactorial, the Candida albicans fungal infection remains the main cause. The objective of the present systematic review was to evaluate the latest literature on the addition of nystatin into the tissue conditioners (TCs) in the management of DIS. To search the published literature about "the addition of nystatin in TCs for treating DIS", electronic databases (PubMed (National library of medicine) and Cochrane Library (Wiley)) were searched (from 1975 until December 2020) using different keywords. Various studies described the effectiveness and efficacy of incorporating nystatin into several TCs. The present systematic review reported that the addition of nystatin is beneficial, with slight or no consequences on both the mechanical and physical features of TCs. Adding nystatin to various TCs for treating DIS can be suggested.
\end{abstract}

Keywords: antifungal; nystatin; tissue conditioner; prosthesis; Candida albicans; denture-induced stomatitis

\section{Introduction}

Denture-induced stomatitis (DIS) is a pathological condition that affects the denture bearing mucosa as a result of trauma from ill-fitting dentures [1,2]. DIS affects a considerable proportion of denture wearers [3]. The primary causal factor of DIS include fungal infections, caused by the Candida species, particularly Candida albicans [4-6]. Nevertheless, the aetiology of DIS can be multifactorial, as other important risk factors, including poor oral hygiene and consistent night-time denture wearing [7], dry mouth [8,9], denture trauma [10], and variation in salivary $\mathrm{pH}$ [11], have been considered to be linked with DIS. Almost two-thirds (65\%) of upper complete denture wearers are affected by this lesion. In the majority of the cases, it is asymptomatic but may present with symptoms of pain, halitosis, pruritus, the presence of erythema/oedema, and burning of the palatine mucosa and gingiva under the denture base [12]. The main diagnosis of the DIS is based on these clinical findings. However, according to some clinicians/researchers, the association of DIS with candidiasis is also considered essential during the diagnosis [13]. For patients 
with symptoms like angular cheilitis/stomatitis, and any other local/systemic lesion, additional diagnostic tests like blood pictures, smears/culture, and, rarely, biopsy of the site may be advised [14,15]. Common signs of DIS are generalised inflammation or a reddish appearance of the hard palate beneath the denture and is much more usual in complete denture wearers [2]. Among the normal oral flora, Candida albicans (C. albicans) is seen in $40 \%$ of the individuals, being part of the dental plaque formation [16]. In certain situations, C. albicans adhering to the constantly worn base of denture results in DIS [17]. In terms of oral fungal infections, C. albicans is the most abundant species and leading pathogen that contributes to the development of DIS $[18,19]$. Besides, Candida tropicalis and Candida glabrata [20] are usually related to the hard palate and the denture surface of healthy denture wearers [21,22].

There is an antifungal protection present in human saliva attributed to the oral antimicrobial peptides [23], but in some conditions-for example, poor oral hygiene-this antifungal defence may not be sufficient. In those cases, denture wearers may require an appropriate treatment. As a result of multifactorial aetiology, the treatment of C. albicans-related DIS is complicated [24,25]. Several therapeutic modalities have been proposed $[18,24]$. The conventional therapies for the treatment of DIS include a local/topical application or oral intake of various antifungal drugs, such as Fluconazole, itraconazole, nystatin, amphotericin B, ketoconazole, and clotrimazole, in addition to the use of mouth washes such as chlorhexidine digluconate $(0.12 \%)$ [26]. The efficacy of these medications ranges from $77 \%$ to $100 \%$ for a clinical and microbiological cure of DIS [27]. Fluconazole and nystatin are the relatively more commonly used drugs for a DIS cure. Fluconazole showed a positive response of $89 \%$, but many relapses were seen in the cases treated with it [28]. Nystatin, in comparison, was shown to be more potent in DIS, with a higher clinical and mycological cure rate and is now considered the standard topical treatment for oral candidiasis [27]. Fungi resistant to nystatin are rare, and also, its cost/availability makes it the drug of choice [29]. However, these treatment options are more or less supportive and may not be beneficial for every individual [30-32]. Photodynamic therapy and the use of nanoparticles are some of the latest/recent treatment modalities used for the cure of DIS. Methylene-blue, toluidine-blue, and porphyrin have been used as photosensitisers in these therapies, for which the results are promising [33]. Some researchers have incorporated nanomaterials such as silver-nanoparticle discs in denture bases for the prevention/treatment of DIS. The results indicated a significant reduction in the adherence of C. albicans [34].

For the conditioning purpose of the denture bearing mucosa, resilient tissue conditioners (TCs) are commonly used. TCs reduce the load endured by denture bearing mucosa, and they also work as a cushion beneath the dentures [35]. Besides, TCs are used as drug delivery carriers $[35,36]$ - for instance, the delivery of antifungal agents for the inhibition of C. albicans $[37,38]$. Due to cognitive impairment, memory loss, and decreased motor activity in geriatric patients, the application of topical antifungal medicaments in DIS patients is challenging [24]. Moreover, maintaining an effective and sustained release of topical antifungal agent is also difficult. Due to regular ingestion and persistent salivary washout, the antifungal drugs are less likely to adhere with the oral mucosa [39]. To overcome these issues, a lot of of research has investigated the efficacy of TCs modified by the addition of various antifungal medicaments, such as nystatin [29,38,40-47], derivatives of the azole group [38,43-47], and chlorhexidine [45-48].

Polyenes, including nystatin, are the main choice for the management of primary oral candidal infections [49]. Nonetheless, there are associated unwanted effects, such as a bitter taste, nausea, mucosal irritation, and poor acceptance by patients [50]. Different studies have investigated the modified TCs with nystatin associated with efficacy [40,41,46,51], drug delivery [38,42], dimensional alterations and stability [52-58], and the stability and time period of the antifungal actions [44]. While there are plenty of studies published, the impact of nystatin in addition to TCs to treat DIS is still not conclusive. Therefore, the aim of the present review was to determine the antifungal potency of nystatin when used 
with different types of TCs for managing patients with DIS. Additionally, the different properties of TCs influencing its effectiveness were reviewed.

\section{Methodology}

This systematic review followed the updated Preferred Reporting Items for Systematic Reviews and Meta-Analysis (PRISMA) reporting guidelines [59].

\subsection{Focus Question}

The focus question designed for this study was

"What is the antifungal potential of "Nystatin" added to different TCs for the management of DIS?"

The PICOS format was used to develop the research question.

Problem (P): Patients with DIS.

Intervention (I): TCs incorporated with nystatin.

Comparison (C): TCs incorporated without nystatin.

Outcomes (O): Antifungal activity, fungal growth inhibition, fungal colonies reduction, fungal adherence, and changes in TC's physical and mechanical properties.

Study designs (S): In-vitro studies, animal studies, and clinical studies.

\subsection{Literature Search}

A systematic search was conducted using electronic databases, PubMed (National Library of Medicine), and the Cochrane Library (Wiley) from January 1975 up to and including December 2020. The following free text keywords were used to carry out the search: "denture induced stomatitis" OR "sore mouth" AND "prosthesis" OR "denture" AND "tissue conditioner" AND "antifungal" OR "nystatin". The bibliographies of the most relevant papers were also searched manually for the identification of eligible studies. Additionally, grey literature was searched using Open Grey.

\subsection{Eligibility Criteria}

The systematic review included original research and clinical studies investigating nystatin added to TCs for antifungal activity. Any research performed using permanent denture base materials, resilient soft liners, and chemically cured acrylics were excluded. Any systematic reviews and narrative reviews, letter to the editor, unpublished data, and opinions were also excluded.

Two independent reviewers (MSS and MSZ) screened the titles, abstracts, and full texts of the eligible papers against the inclusion and exclusion criteria. Any disagreement was discussed and solved by consensus. The kappa coefficient $(\kappa)$ was used to evaluate the inter-rater agreement between the study authors [60].

\subsection{Data Extraction}

The following data was extracted from the included studies:

- Publication year and authors details.

- Experimental group(s) reported by the study.

- TC used with nystatin.

- Main results of the study.

\subsection{Quality Assessment}

The quality assessment of the included studies was analysed by the Risk Of Bias In Non-randomized Studies-of Interventions (ROBINS-I), a novel tool for appraising the risk of bias from studies not using randomisation to assign units to comparison groups [61]. For the animal interventional study, Systematic Review Centre for Laboratory animal Experimentation (SYRCLE) (a risk of bias tool) was used [62]. Two authors (MSS and MSZ) independently performed the quality assessment of the included papers. 


\section{Results}

The initial title search led to a total of 655 articles after removing the duplicates. Following the title screening, 35 abstracts were selected. A thorough screening of the abstracts resulted in total of 26 articles [30,40,41,43,45,47,48,53-58,63-75]. Furthermore, nine articles $[29,38,42,44,46,51,52,76,77]$ were added as a result of manual search, making a total of 35 articles for full text evaluations (Figure 1). The reading of the 35 full-text articles permitted the selection of 25 studies (one animal study [47], three clinical studies [38,41,51], and 21 in-vitro studies $[29,40,42-46,52-58,63,66,70,72,74-76])$ meeting the inclusion criteria of this systematic review, and 10 articles were excluded (Table 1). A meta-analysis (quantitative analysis) was not possible due to the high heterogeneity between the data of the included studies; therefore, only a qualitative analysis was performed.
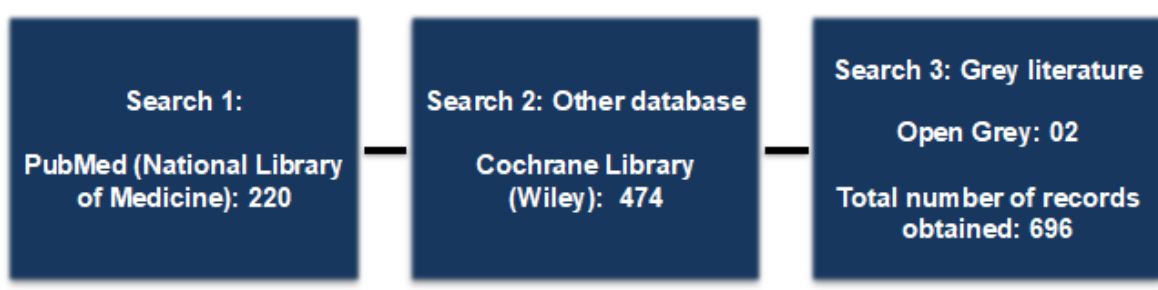

Total records obtained after de-duplication: $696-41: 655$
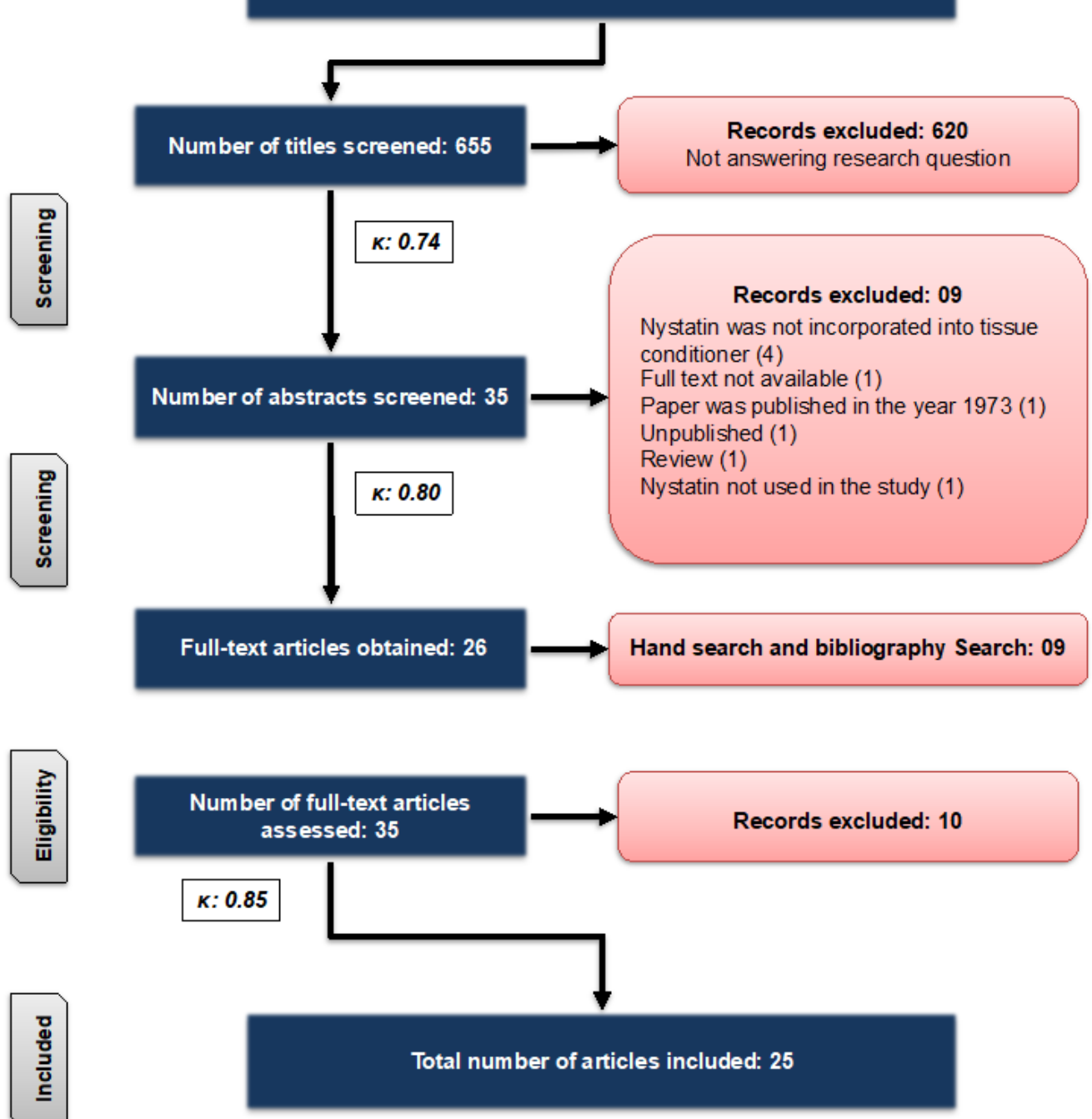

Figure 1. Flowchart showing the search strategies used for the literature search. 
Table 1. Studies excluded after the full text assessment, including the reasons.

\begin{tabular}{cc}
\hline Reason for Exclusion & References \\
\hline Nystatin was not incorporated into tissue conditioner & {$[30,64,68,69,73]$} \\
Nystatin was used as a mouth rinse & {$[67-71]$} \\
Full text not available & {$[65]$} \\
Nystatin not used in the study & {$[48]$} \\
Nystatin-alginate composite was used & {$[77]$} \\
\hline
\end{tabular}

Cohen's Kappa score is always less than or equal to one. A value of one indicates a perfect agreement, and values less than one imply less than perfect agreement. It is possible that Cohen's Kappa score is in the negatives, suggesting that the two reviewers agreed less than would be expected just by chance. The extent of inter-rater reliability between the two reviewers was tested using Cohen's Kappa coefficient. The calculated scores of Cohen's Kappa statistic $\kappa$ were $0.74,0.80$, and 0.85 (Figure 1 ), indicating substantial to almost perfect agreement [60]. The characteristics of the included papers are demonstrated in Table 2.

Table 2. Characteristics of the studies included in the present review.

\begin{tabular}{|c|c|c|c|}
\hline Study & Experimental Group(s) & TC and Nystatin & Key Outcomes \\
\hline & \multicolumn{3}{|c|}{ In-vitro studies } \\
\hline Douglas and Clarke (1975) [63] & $\begin{array}{c}\text { Nystatin }+ \text { Coe comfort } \\
\text { Control }\end{array}$ & Coe comfort & $\begin{array}{l}\text { Improved physical and mechanical } \\
\text { properties of the denture liners by the } \\
\text { addition of nystatin. }\end{array}$ \\
\hline Thomas and Nutt (1978) [76] & $\begin{array}{c}\text { Nystatin + Viscogel } \\
\text { Amphotericin B + Viscogel } \\
\text { Control }\end{array}$ & Viscogel & $\begin{array}{l}\text { Nystatin demonstrated more effective } \\
\text { outcomes in comparison to } \\
\text { amphotericin B and control. }\end{array}$ \\
\hline Schneid (1992) [52] & $\begin{array}{c}\text { Nystatin + Lynal C/Temporary } \\
\text { Reliner } \\
\text { Chlorhexidine + Lynal } \\
\text { TC/Temporary Reliner } \\
\text { Clotrimazole + Lynal } \\
\text { TC/Temporary Reliner } \\
\text { Fluconazole + Lynal } \\
\text { TC/Temporary Reliner } \\
\text { Control }\end{array}$ & $\begin{array}{c}\text { Lynal TC } \\
\text { Temporary Reliner }\end{array}$ & $\begin{array}{l}\text { Nystatin exhibited the growth inhibition } \\
\text { of C. albicans and release from the TC } \\
\text { matrix, which was either total, } \\
\text { dose-related, or related to the incubation } \\
\text { period prior to the inoculation. }\end{array}$ \\
\hline Truhlar et al. (1994) [66] & $\begin{array}{c}\text { Nystatin + Lynal/Viscogel } \\
\text { Control }\end{array}$ & $\begin{array}{c}\text { Lynal } \\
\text { Viscogel }\end{array}$ & $\begin{array}{l}\text { Incorporating a dose of nystatin into the } \\
\text { reline material permitted release of the } \\
\text { agent over } 2 \text { weeks' time, warranting a } \\
\text { high long-term dosage. Insignificant } \\
\text { antifungal activity was showed by the } \\
\text { control group. }\end{array}$ \\
\hline Chow et al. (1999) [40] & $\begin{array}{c}\text { Nystatin }+ \text { Coe soft/Viscogel/Fitt } \\
\text { Fluconazole }+ \text { Core } \\
\text { soft/Viscogel/Fitt } \\
\text { Itraconazole }+ \text { Coe } \\
\text { soft/Viscogel/Fitt } \\
\text { Control }\end{array}$ & $\begin{array}{l}\text { Coe Soft } \\
\text { Viscogel } \\
\text { Fitt }\end{array}$ & $\begin{array}{l}\text { Nystatin was found to be effectual as } \\
\text { compared to the control group; however, } \\
\text { in comparison with the other } \\
\text { antifungals, it was the least efficient. }\end{array}$ \\
\hline Urban et al. (2006) [53] & $\begin{array}{c}\text { Nystatin }+ \text { Dure conditioner } \\
\text { Control }\end{array}$ & Dura conditioner & $\begin{array}{c}\text { At greater concentrations and after } 24 \mathrm{~h} \text {, } \\
\text { the tensile strength of the TC was } \\
\text { considerably improved by the addition } \\
\text { of nystatin. }\end{array}$ \\
\hline Urban et al. (2009) [54] & $\begin{array}{c}\text { Nystatin + Softone } \\
\text { Chlorhexidine diacetate + Softone } \\
\text { Ketoconazole }+ \text { Softone } \\
\text { Miconazole }+ \text { Softone } \\
\text { Control }\end{array}$ & Softone & $\begin{array}{l}\text { Nystatin specimens exhibited particles } \\
\text { with irregular shapes and sizes } \\
\text { consistently distributed. The modified } \\
\text { TC demonstrated differences in the } \\
\text { particle distribution and nystatin size } \\
\text { added to the plasticised matrix. }\end{array}$ \\
\hline Falah-Tafti et al. (2010) [29] & $\begin{array}{c}\text { Nystatin }+ \text { Acrosoft } \\
\text { Ketoconazole }+ \text { Acrosoft } \\
\text { Control }\end{array}$ & Acrosoft & $\begin{array}{l}\text { TC added with nystatin can totally } \\
\text { impede the adhesion, as well as } \\
\text { colonisation, of } C \text {. albicans. }\end{array}$ \\
\hline
\end{tabular}


Table 2. Cont.

\begin{tabular}{|c|c|c|c|}
\hline Study & Experimental Group(s) & TC and Nystatin & Key Outcomes \\
\hline Julian et al. (2010) [42] & $\begin{array}{c}\text { Nystatin + Viscogel } \\
\text { Ketoconazole + Viscogel } \\
\text { Clotrimazole + Viscogel }\end{array}$ & Viscogel & $\begin{array}{l}\text { The TC can be used as an effective } \\
\text { delivery system for nystatin. It also } \\
\text { revealed the acrylic matrix efficiency for } \\
\text { dispersion of the drug into the } \\
\text { surrounding medium at constant } \\
\text { therapeutic levels. }\end{array}$ \\
\hline Chopde et al. (2012) [43] & $\begin{array}{l}\text { Nystatin + Viscogel/GC soft } \\
\text { Miconazole + Viscogel/GC soft } \\
\text { Fluconazole + Viscogel/GC soft }\end{array}$ & $\begin{array}{l}\text { Viscogel } \\
\text { GC Soft }\end{array}$ & $\begin{array}{c}\text { Nystatin displayed an improved } \\
\text { inhibition of } C \text {. albicans compared to the } \\
\text { control group, but in comparison with } \\
\text { the other antifungals, it was the least } \\
\text { efficient. }\end{array}$ \\
\hline Fallah-Tafti et al. (2014) [44] & $\begin{array}{c}\text { Nystatin + GC soft } \\
\text { Fluconazole + GC soft }\end{array}$ & GC Soft & $\begin{array}{l}\text { Nystatin showed greater inhibitory } \\
\text { effects than fluconazole; nevertheless, } \\
\text { the stability of nystatin added to TC was } \\
\text { not adequate, and the antifungal effects } \\
\text { were comprehended only for } 3 \text { days. }\end{array}$ \\
\hline
\end{tabular}

\begin{tabular}{|c|c|c|c|}
\hline Urban et al. (2015) [55] & $\begin{array}{c}\text { Nystatin + Trusoft/Softone } \\
\text { Miconazole + Trusoft/Softone } \\
\text { Ketoconazole + Trusoft/Softone } \\
\text { Itraconazole + Trusoft/Softone } \\
\text { Chlorhexidine diacetate + } \\
\text { Trusoft/Softone } \\
\text { Control }\end{array}$ & $\begin{array}{l}\text { Trusoft } \\
\text { Softone }\end{array}$ & $\begin{array}{l}\text { Nystatin showed an increase in the } \\
\text { hardness of soft materials with time. }\end{array}$ \\
\hline Bueno et al. (2015) [45] & $\begin{array}{l}\text { Nystatin + Trusoft/Softone } \\
\text { Miconazole + Trusoft/Softone } \\
\text { Ketoconazole + Trusoft/Softone } \\
\text { Itraconazole + Trusoft/Softone } \\
\text { Chlorhexidine diacetate+ } \\
\text { Trusoft/Softone; Control }\end{array}$ & $\begin{array}{l}\text { Trusoft } \\
\text { Softone }\end{array}$ & $\begin{array}{l}\text { Nystatin incorporation into the resilient } \\
\text { materials hindered fungal growth } \\
\text { during } 2 \text { weeks; however, with a lower } \\
\text { MIC in comparison to other antifungals. }\end{array}$ \\
\hline Lima et al. (2016a) [56] & $\begin{array}{c}\text { Nystatin }+ \text { Trusoft/Softone } \\
\text { Chlorhexidine diacetate }+ \\
\text { Trusoft/Softone } \\
\text { Ketoconazole + Trusoft/Softone } \\
\text { Control }\end{array}$ & $\begin{array}{l}\text { Trusoft } \\
\text { Softone }\end{array}$ & $\begin{array}{l}\text { Nystatin addition at the MIC in TC did } \\
\text { not affect water sorption the following } 2 \\
\text { weeks. The solubility of the two interim } \\
\text { materials was unaltered by the addition } \\
\text { of nystatin for up to } 2 \text { weeks. }\end{array}$ \\
\hline Lima et al. (2016b) [57] & $\begin{array}{c}\text { Nystatin }+ \text { Trusoft/Softone } \\
\text { Chlorhexidine diacetate }+ \\
\text { Trusoft/Softone } \\
\text { Ketoconazole + Trusoft/Softone } \\
\text { Control }\end{array}$ & $\begin{array}{l}\text { Trusoft } \\
\text { Softone }\end{array}$ & $\begin{array}{l}\text { Nystatin addition in Trusoft at the MIC } \\
\text { caused no harmful effects of the porosity } \\
\text { at different periods of water immersion } \\
\text { at } 2 \text { weeks. Following } 2 \text { weeks, no } \\
\text { detrimental effect was noted for the TC } \\
\text { porosity modified by nystatin at the } \\
\text { MIC. }\end{array}$ \\
\hline Sánchez-Aliaga et al. (2016) [70] & $\begin{array}{l}\text { Nystatin + Trusoft/Softone } \\
\text { Miconazole + Trusoft/Softone } \\
\text { Ketoconazole + Trusoft/Softone } \\
\text { Itraconazole + Trusoft/Softone } \\
\text { Chlorhexidine diacetate+ } \\
\text { Trusoft/Softone; Control }\end{array}$ & $\begin{array}{l}\text { Trusoft } \\
\text { Softone }\end{array}$ & $\begin{array}{l}\text { Nystatin incorporation did not result in } \\
\text { values below those recommended for } \\
\text { the peel bond strength after } 1 \text { and } 2 \\
\text { weeks of evaluation. }\end{array}$ \\
\hline Barua et al. (2017) [46] & $\begin{array}{c}\text { Nystatin + Viscogel } \\
\text { Neem leaf extract + Viscogel } \\
\text { Ketoconazole + Viscogel } \\
\text { Chlorhexidine diacetate }+ \\
\text { Viscogel } \\
\text { Control group }\end{array}$ & Viscogel & $\begin{array}{l}\text { Nystatin was favourably efficient in } \\
\text { inhibiting the growth of } C \text {. albicans. }\end{array}$ \\
\hline Bueno et al. (2017) [72] & $\begin{array}{c}\text { Nystatin + Trusoft/Softone } \\
\text { Miconazole + Trusoft/Softone } \\
\text { Ketoconazole + Trusoft/Softone } \\
\text { Itraconazole + Trusoft/Softone } \\
\text { Chlorhexidine diacetate + } \\
\text { Trusoft/Softone } \\
\text { Control }\end{array}$ & $\begin{array}{l}\text { Trusoft } \\
\text { Softone }\end{array}$ & $\begin{array}{l}\text { Nystatin MIC in both the TC } \\
\text { determined no unfavourable effects for } \\
\text { roughness up to } 2 \text { weeks. }\end{array}$ \\
\hline
\end{tabular}


Table 2. Cont.

\begin{tabular}{|c|c|c|c|}
\hline Study & Experimental Group(s) & TC and Nystatin & Key Outcomes \\
\hline Neppelenbroek et al. (2018) [74] & $\begin{array}{c}\text { Nystatin + Trusoft/Softone } \\
\text { Miconazole + Trusoft/Softone } \\
\text { Ketoconazole + Trusoft/Softone } \\
\text { Itraconazole + Trusoft/Softone } \\
\text { Chlorhexidine diacetate + } \\
\text { Trusoft/Softone } \\
\text { Control }\end{array}$ & $\begin{array}{l}\text { Trusoft } \\
\text { Softone }\end{array}$ & $\begin{array}{c}\text { The MIC of nystatin for C. albicans } \\
\text { caused no harmful effects on the tensile } \\
\text { strength and elongation percentage of } \\
\text { the temporary soft denture liners up to } 2 \\
\text { weeks. }\end{array}$ \\
\hline Homsiang et al. (2020) [58] & $\begin{array}{c}\text { Nystatin + GC soft } \\
\text { ZnOnps + GC soft } \\
\text { Control }\end{array}$ & GC Soft & $\begin{array}{l}\text { Nystatin provided a suitable antifungal } \\
\text { effect up to } 2 \text { weeks, with no adverse } \\
\text { effects on the TC penetration depth and } \\
\text { tensile bond strength. }\end{array}$ \\
\hline
\end{tabular}

\begin{tabular}{|c|c|c|c|}
\hline Bassi et al. (2020) [75] & $\begin{array}{c}\text { Four preconditioning systems: } \\
\text { Foetal bovine serum, artificial } \\
\text { saliva, artificial saliva + foetal } \\
\text { bovine serum and } \\
\text { phosphate-buffered saline } \\
\text { Nystatin + Silagum-Comfort } \\
\text { Fluconazole + Silagum-Comfort } \\
\text { Amphotericin B + } \\
\text { Silagum-Comfort }\end{array}$ & Silagum-Comfort & $\begin{array}{l}\text { Nystatin showed more effective results } \\
\text { in reducing } C \text {. albicans biofilm metabolic } \\
\text { activity dependent on time and its } \\
\text { concentrations. }\end{array}$ \\
\hline & \multicolumn{3}{|c|}{ Clinical studies } \\
\hline Geerts et al. (2008) [41] & Nystatin + Viscogel & Viscogel & $\begin{array}{l}\text { Nystatin containing short-term denture } \\
\text { liner considerably reduced the salivary } \\
\text { yeast count of individuals with DIS. }\end{array}$ \\
\hline Ibraheem and Dehis (2016) [51] & $\begin{array}{c}\text { Nystatin + Viscogel } \\
\text { Control }\end{array}$ & Viscogel & $\begin{array}{l}\text { Nystatin mixed with TC demonstrated } \\
\text { no noticeable effect on C. albicans } \\
\text { inhibition. }\end{array}$ \\
\hline \multirow[t]{2}{*}{ Kumar et al. (2020) [38] } & $\begin{array}{c}\text { Nystatin + TC } \\
\text { Fluconazole+ TC }\end{array}$ & NR & $\begin{array}{l}\text { Nystatin was effective against } C \text {. albicans } \\
\text { and can be an effective treatment } \\
\text { compared to fluconazole in DIS. }\end{array}$ \\
\hline & \multicolumn{3}{|c|}{ Animal study } \\
\hline Hotta et al. (2019) [47] & $\begin{array}{c}\text { Nystatin }+ \text { Trusoft } \\
\text { Chlorhexidine diacetate }+ \text { Trusoft } \\
\text { Ketoconazole }+ \text { Trusoft } \\
\text { Control }\end{array}$ & Trusoft & $\begin{array}{c}\text { Incorporation of nystatin MIC to TC did } \\
\text { not prompt histopathological variations } \\
\text { in the rat palatal mucosa, signifying the } \\
\text { in vivo biocompatibility of the DIS } \\
\text { treatment. }\end{array}$ \\
\hline
\end{tabular}

C. albicans (Candida albicans), DIS (Denture-induced stomatitis), MIC (Minimum inhibitory concentration), NR (Not reported), TC (Tissue conditioner), and ZnOnps (Zinc oxide nanoparticles).

\subsection{Types of Study Designs}

Out of 25 papers, one was an animal study [47], three were clinical studies [38,41,51], and the remaining 21 were in-vitro studies $[29,40,42-46,52-58,63,66,70,72,74-76]$.

\subsection{Types of TCs Used with Nystatin}

Different TCs were used in various studies (Table 2). The most commonly used TC was Viscogel [40-43,46,51,66,76] and Trusoft and Softone [45,47,54-57,70,72,74], followed by GC soft liner [43,44,58], Lynal [52,66], Fitt [40], Dura conditioner [53], Acrosoft [29], Coe comfort [63], Coe soft [40], and Silagum-Comfort [75]. However, one study did not report the TC [38].

\subsection{Antifungal Potential of Nystatin When Added to TCs}

The use of nystatin added to the TCs was investigated against $C$. albicans for their effectiveness and efficacy in decreasing the DIS. This combination has been reported for its effectiveness and stability $[40,41,45,46,74]$; however, the duration of the efficiency remains debatable. One study reported a maximum effectiveness for $48 \mathrm{~h}$ [75], two studies for $72 \mathrm{~h}[40,44]$, one study for 1 week [41], and six studies reported an effectiveness for up to 2 weeks $[45,56-58,72,74]$. 
For the treatment of DIS, various combinations of nystatin and TCs were investigated for their efficacy in reducing the growth of fungus and colony numbers. Most of the studies contemplated it as considerably successful if there was candidal growth inhibition after the topical nystatin application added with the TCs $[40,46,52,66]$. Otherwise, the antifungal action of the TCs added with nystatin was evaluated. A reduction or absence in candidal colonies after applying nystatin TC was considered beneficial $[38,41,43,51,58,76]$. A few studies evaluated the fungal adherence to the denture base or soft liners. A decrease in the adhesion or formation of a microbial biofilm was considered successful [29,45]. Recently, one study investigated the growth kinetics of $C$. albicans and reported that nystatin was the most effective antifungal in reducing the fungal metabolic activity [75]. While the criteria for the meaningful outcomes were not homogenous in the papers included, a majority of the studies established that a $C$. albicans reduction may considerably influence the management of DIS.

\subsection{Effect of Nystatin on the Properties of TCS}

Several studies reported the impact of nystatin on the properties of TCs, such as tensile strength [53,58,74], particle size and distribution [54], shore A hardness and roughness [55], water sorption [56], porosity [57], peel bond strength [70], and surface properties [72]. Most of the studies demonstrated no significant changes in the mechanical, as well as physical, properties of the TCs added with nystatin, showing no harmful effects of the antifungal drug $[53,56-58,70,72,74]$. In one study, minor changes with the passage of time in the hardness and roughness of the TC was reported [55]. More recently, an in vivo study demonstrated that an application of nystatin added to a TC to rat palatal mucosa did not significantly induce histopathological changes [47], suggesting its in vivo biocompatibility.

\subsection{Quality Assessment}

The quality assessment of the clinical studies is shown in Figure 2 using the ROBINS-I tool [61]. All the three clinical studies $[38,41,51]$ in this analysis were classified to have a moderate risk of bias. The SYRCLE tool [62] used for the quality assessment of one animal study [47] is given in Figure 3, and it was categorised as an unclear risk of bias.

\begin{tabular}{|c|c|c|c|c|c|c|c|c|}
\hline Study & 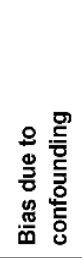 & 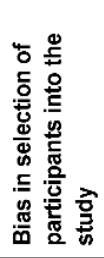 & 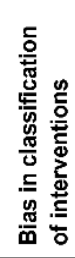 & 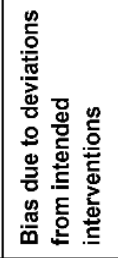 & 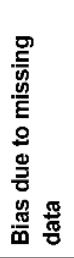 & 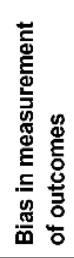 & 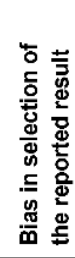 & 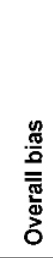 \\
\hline \multicolumn{9}{|l|}{ Geerts et al. (2008) } \\
\hline \multicolumn{9}{|c|}{ Ibrahim and Dehis (2016) } \\
\hline Kumar et al. (2020) & & & & & & & & \\
\hline
\end{tabular}

\begin{tabular}{|l|l|}
\hline Low risk of bias & \\
\hline Moderate risk of bias & \\
\hline Serious risk of bias & \\
\hline Critical risk of bias & \\
\hline No information & \\
\hline
\end{tabular}

Figure 2. Risk of bias in the nonrandomised studies of interventions with individual domains and the overall result. 


\begin{tabular}{|c|c|c|c|c|c|c|c|c|c|c|}
\hline & \multicolumn{3}{|c|}{ Selection bias } & \multicolumn{2}{|c|}{$\begin{array}{l}\text { Performance } \\
\text { bias }\end{array}$} & \multicolumn{2}{|c|}{ Detection bias } & \multirow{2}{*}{ 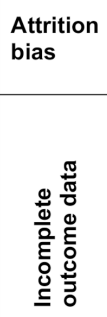 } & \multirow{2}{*}{ 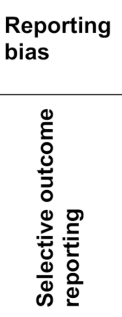 } & \multirow{2}{*}{ 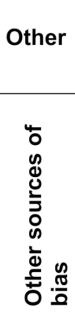 } \\
\hline Study & 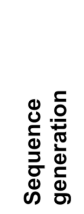 & 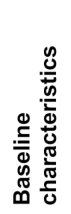 & 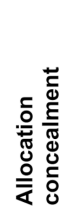 & 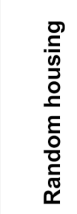 & 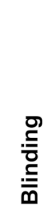 & 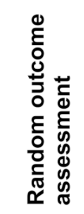 & 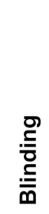 & & & \\
\hline Hotta et al. (2018) & & & & & & & & & & \\
\hline
\end{tabular}

\begin{tabular}{|l|l|}
\hline Low risk of bias \\
\hline Unclear risk of bias \\
\hline High risk of bias \\
\hline
\end{tabular}

Figure 3. Risk of bias in an animal study of intervention with individual domains using the Systematic Review Centre for Laboratory animal Experimentation (SYRCLE) tool.

\section{Discussion}

The results from the studies evaluated suggest that the majority of them showed favourable outcomes for adding nystatin to TCs. The treatment of DIS is both multifactorial and complicated, taking into consideration the contributing and aetiological factors $[12,18,24,25,32]$. The denture base materials with added nystatin proved to be a successful treatment modality for cases with DIS [29,38,40,43,45,47,58]. Douglas and Walker (1973) introduced the concept of using nystatin in denture liners around four decades ago. Following that, a significant level of research has been performed to enhance the effectiveness, as well as efficacy, of nystatin added to TCs [78]. The use of nystatin has been commonly documented for the treatment of oral candida infections such as DIS [79-82]. Likewise, nystatin has been widely used with a variety of TCs $[38,41-43,45,46]$ and exhibited very favourable results related to the reduction of fungal growth.

A study conducted four decades ago showed an effective antifungal activity of nystatin added to various TCs [78]. In another study, nystatin was steadily released from the TCs to the saliva, lessening the salivary yeasts for a limited time period [41]. Furthermore, in a recent animal study, the in-vivo biocompatibility of DIS was determined due to the fact that incorporating nystatin into the TC did not induce histopathological variations in the rat palatal mucosa [47]. More lately, the growth kinetics of $C$. albicans were investigated, and the results showed a maximum effectiveness for the antifungal nystatin rather than the other antifungals [75]. Concerning the effective stability and time duration of nystatin added to TCs, the studies ranged between three days to one week $[40,41,44,70]$ or to a maximum of two weeks $[45,56-58,72,74]$.

The stability and duration were directly controlled by several factors, including the chemical nature and concentration $[38,45,52,72]$. Regarding the nystatin concentration, different studies used different concentrations, varying from 500,000 U to 1,000,000 U; therefore, no agreement has been given related to an effective nystatin concentration $[29,41,42,55,66]$. However, most of latest studies reported different units of measurement for the nystatin concentrations, i.e., $0.032 \mathrm{~g}[56,57,70,72,74]$. This variability between the doses and units of measurements in nystatin made it difficult to conduct a meta-analysis.

Beside nystatin, other antifungal medicaments have also been assessed for their antifungal potency, including the derivatives of the azole group, i.e., clotrimazole, fluconazole, itraconazole, ketoconazole, and miconazole $[40,42,45,48,83]$. These drugs are very comparable to nystatin in terms of efficacy and antifungal activity $[42,45,47,74]$.

For the treatment of mucosal lesions, nystatin is considered to be both a safe and potent antifungal for topical, as well as systemic, applications. Nystatin is one of the drugs of choice to treat oral infections of fungal origin. Though the topical application of nystatin is considered to be effective and safe, a prolonged systemic use can lead to detrimental 
effects on the liver and kidneys $[29,38,41-43,45]$. The topical application of nystatin is potent against a fungal infection invading the superficial tissues, but this can be linked to a few adverse effects, such as bad taste and the requirement of repeated applications. This, in turn, may lead to inadequate patient compliance, influencing the treatment outcomes further $[38,40,41,51]$.

The topical application of nystatin four times per day for two weeks was effective in the treatment of DIS $[18,19]$. Furthermore, the concurrent administration of suspension and nystatin tablets for 15 days yielded a higher rate of clinical, as well mycological, cures in comparison to a monotherapy [27]. A topical nystatin application in combination with amphotericin B also demonstrated a considerable clinical result [84]. Finally, while comparing the nystatin and fluconazole efficacy in the management of DIS, it was summarised that nystatin is the standard topical treatment for oral candidiasis, with the total inhibition of both the binding and colonisation of C. albicans [29]. The uncommon presence of nystatinresistant fungi and its affordable cost are the other advantages of this drug compared to other antifungals [41]. Hota et al. [47] advocated the biocompatibility and feasibility of the incorporation of chlorhexidine and nystatin to the TCs for the treatment of DIS, as no histopathological changes were observed in the palatal mucosa of rats.

Moreover, the studies reported different effective durations, which were based on the type of TCs used with nystatin, such as two days [75], three days [40,44], one week [41], and two weeks $[45,56-58,72,74]$. Taking into consideration the results of the analysed papers, an efficacious time period of one to two weeks may be recommended to get adequate results of the nystatin therapy. Nevertheless, an ideal time period of nystatin added to the TCs for achieving the desired outcomes may not be determined to date and necessitates more research in this area. A study reported that the yeasts completely disappeared following 15 days of nystatin treatment [85]. Nevertheless, few studies reported a faster fungal regrowth in both the oral cavity and alimentary tract $[85,86]$. Following two weeks of nystatin withdrawal, the fungal colonies on the base of the dentures and denture-bearing mucosa were similar to those found initially. This fungal regrowth can be reduced if nystatin is administered over a longer period, such as four-six weeks [87]. Therefore, for the treatment of DIS, the exposure of the antifungal for a long time period is needed. Adding to that, the overuse of nystatin is not free from adverse effects and the development of resistant strains of the fungus [88-90]. Among the various medicaments, nystatin and chlorhexidine remain the most incorporated medicaments in the TCs for the treatment of DIS [91].

The studies included in the present review analysed altered TCs by their nystatin addition. This addition may interfere the setting reaction of TCs or alter the mechanical and physical characteristics. For achieving the ideal results, the properties of TCs should not be disrupted because of a nystatin addition. Certain studies demonstrated no alterations in the mechanical properties-for example, tensile strength $[53,58,74]$, water sorption and solubility [56], porosity [57], peel bond strength [70], and hardness and roughness [72]. On the contrary, one study exhibited slight alterations in the hardness, as well as roughness, with the passage of time [55].

This variation in the outcomes may be attributed to the different concentrations and materials of the applied nystatin. Apart from that, the additive particle size may also impact the drug filtering from the plasticised matrix of the TCs [54]. For instance, the high surface area and reactivity of nanoparticles may lead to an acceleration of the drug release [92]. While nystatin and TCs with varied strengths were examined, the outcomes of the papers revealed no-to-slight modifications in the mechanical, as well as physical, characteristics of the TCs. Nonetheless, additives may probably affect the properties of materials if they impede the TC polymerisation or react chemically.

Few limitations pertain to this current systematic review. The studies reported a broad range of heterogeneity considering the methodology, outcomes, nystatin concentrations, and dimensional variations of the TCs. These variations did not permit a meta-analysis and, consequently, the application of the Grading of Recommendations, Assessment, 
Development and Evaluation (GRADE) approach, which is the most commonly adopted tool for grading the quality of evidence and for making recommendations of quantitative data for each outcome. Out of the included studies, only a limited number of studies were in-vivo experiments (one animal and three clinical) $[38,41,51]$. Most of the studies were in-vitro laboratory-based studies with or without imitating clinical situations. Moreover, a quality assessment of the in-vitro studies could not be conducted, as there was no standard tool available for a critical appraisal of the in-vitro studies.

\section{Conclusions}

From the above-mentioned discussion, it can be summarised that the addition of nystatin into TCs can be advocated for treating patients with DIS. Nevertheless, for the future, more studies are necessary to solve the still-open questions-for instance, optimum dosage, drug release control, and TC stability. Furthermore, randomised controlled clinical trials are much needed for improving the antifungal efficacy for DIS patients.

Author Contributions: Conceptualization: M.S.Z., S.R.H. and M.S.S. Methodology: M.S.S. and A.A. Writing original draft: M.S.S. and M.A.L. Writing review and editing: M.S.Z. and S.R.H. Project administration: M.S.Z. All authors have read and agreed to the published version of the manuscript.

Funding: This research received no external funding.

Institutional Review Board Statement: Not applicable.

Informed Consent Statement: Not applicable.

Data Availability Statement: Data supporting the reported results can be found at PubMed (https: / / pubmed.ncbi.nlm.nih.gov) and Cochrane Library (https:/ / www.cochranelibrary.com).

Conflicts of Interest: The authors declare no conflict of interest.

\section{References}

1. Shulman, J.; Rivera-Hidalgo, F.; Beach, M. Risk factors associated with denture stomatitis in the United States. J. Oral Pathol. Med. 2005, 34, 340-346. [CrossRef] [PubMed]

2. Gendreau, L.; Loewy, Z.G. Epidemiology and etiology of denture stomatitis. J. Prosthodont. 2011, 20, 251-260. [CrossRef] [PubMed]

3. Pachava, K.R.; Nadendla, L.K.; Alluri, L.S.C.; Tahseen, H.; Sajja, N.P. Invitro antifungal evaluation of denture soft liner incorporated with tea tree oil: A new therapeutic approach towards denture stomatitis. J. Clin. Diagn. 2015, 9, ZC62-ZC64. [CrossRef] [PubMed]

4. Kulak, Y.; Arikan, A. Aetiology of denture stomatitis. J. Marmara Univ. Dent. Fac. 1993, 1, 307-314.

5. Ramage, G.; Tomsett, K.; Wickes, B.L.; López-Ribot, J.L.; Redding, S.W. Denture stomatitis: A role for Candida biofilms. Oral Surg. Oral Med. Oral Pathol. Oral Radiol. Endod. 2004, 98, 53-59. [CrossRef]

6. Pereira-Cenci, T.; Del Bel Cury, A.A.; Crielaard, W.; Ten Cate, J.M. Development of Candida-associated denture stomatitis: New insights. J. Appl. Oral Sci. 2008, 16, 86-94. [CrossRef]

7. Evren, B.A.; Uludamar, A.; Işeri, U.; Ozkan, Y.K. The association between socioeconomic status, oral hygiene practice, denture stomatitis and oral status in elderly people living different residential homes. Arch. Gerontol. Geriatr. 2011, 53, 252-257. [CrossRef]

8. Shinozaki, S.; Moriyama, M.; Hayashida, J.N.; Tanaka, A.; Maehara, T.; Ieda, S.; Nakamura, S. Close association between oral Candida species and oral mucosal disorders in patients with xerostomia. Oral Dis. 2012, 18, 667-672. [CrossRef]

9. Nadig, S.D.; Ashwathappa, D.T.; Manjunath, S.K.M.; Annaji, A.G.; Shivaprakash, P.K. A relationship between salivary flow rates and Candida counts in patients with xerostomia. J. Oral Maxillofac. Pathol. 2017, 21, 316. [CrossRef]

10. Emami, E.; De Grandmont, P.; Rompré, P.; Barbeau, J.; Pan, S.; Feine, J. Favoring trauma as an etiological factor in denture stomatitis. J. Dent. Res. 2008, 87, 440-444. [CrossRef]

11. Lombardi, T.; Budtz-Jørgensen, E. Treatment of denture-induced stomatitis: A review. Eur. J. Prosthodont. Restor. Dent. 1993, 2, 17-22. [PubMed]

12. Martins, K.V.; de Lacerda Gontijo, S.M. Treatment of denture stomatitis: Literature review. Revistas 2017, 74, 215-220. [CrossRef]

13. Aoun, G.; Berberi, A. Prevalence of Chronic erythematous candidiasis in Lebanese denture wearers: A clinico-microbiological study. Mater. Sociomed. 2017, 29, 26. [CrossRef] [PubMed]

14. Moosazadeh, M.; Akbari, M.; Tabrizi, R.; Ghorbani, A.; Golkari, A.; Banakar, M.; Sekhavati, E.; Kavari, S.H.; Lankarani, K.B. Denture stomatitis and Candida albicans in Iranian population: A systematic review and meta-analysis. J. Dent. 2016, 17, 283.

15. Byrd, W.C.; Schwartz-Baxter, S.; Carlson, J.; Barros, S.; Offenbacher, S.; Bencharit, S. Role of salivary and candidal proteins in denture stomatitis: An exploratory proteomic analysis. Mol. Biosyst. 2014, 10, 2299-2304. [CrossRef] 
16. Darwazeh, A.M.-G.; Al-Refai, S.; Al-Mojaiwel, S. Isolation of Candida species from the oral cavity and fingertips of complete denture wearers. J. Prosthet. Dent. 2001, 86, 420-423. [CrossRef]

17. Barbeau, J.; Séguin, J.; Goulet, J.P.; de Koninck, L.; Avon, S.L.; Lalonde, B.; Rompré, P.; Deslauriers, N. Reassessing the presence of Candida albicans in denture-related stomatitis. Oral Surg. Oral Med. Oral Pathol. Oral Radiol. Endod. 2003, 95, 51-59. [CrossRef]

18. Silva, M.M.; de Oliveira Mima, E.G.; Colombo, A.L.; Sanitá, P.V.; Jorge, J.H.; Massucato, E.M.S.; Vergani, C.E. Comparison of denture microwave disinfection and conventional antifungal therapy in the treatment of denture stomatitis: A randomized clinical study. Oral Surg. Oral Med. Oral Pathol. Oral Radiol. 2012, 114, 469-479. [CrossRef]

19. Mima, E.; Vergani, C.E.; Machado, A.L.; Massucato, E.M.S.; Colombo, A.L.; Bagnato, V.S.; Pavarina, A.C. Comparison of Photodynamic Therapy versus conventional antifungal therapy for the treatment of denture stomatitis: A randomized clinical trial. Clin. Microbiol. Infect. 2012, 18, E380-E388. [CrossRef]

20. Monteiro, D.R.; Takamiya, A.S.; Feresin, L.P.; Gorup, L.F.; de Camargo, E.R.; Delbem, A.C.B.; Henriques, M.; Barbosa, D.B. Susceptibility of Candida albicans and Candida glabrata biofilms to silver nanoparticles in intermediate and mature development phases. J. Prosthodont. Res. 2015, 59, 42-48. [CrossRef]

21. Baena-Monroy, T.; Moreno-Maldonado, V.; Franco-Martínez, F.; Aldape-Barrios, B.; Quindós, G.; Sánchez-Vargas, L.O. Candida albicans, Staphylococcus aureus and Streptococcus mutans colonization in patients wearing dental prosthesis. Med. Oral Patol. Oral Cir. Bucal 2005, 10, E27-E39. [PubMed]

22. Hoshi, N.; Mori, H.; Taguchi, H.; Taniguchi, M.; Aoki, H.; Sawada, T.; Kawabata, M.; Kuwabara, A.; Oono, A.; Tanaka, K. Management of oral candidiasis in denture wearers. J. Prosthodont. Res. 2011, 55, 48-52. [CrossRef]

23. Khurshid, Z.; Naseem, M.; Sheikh, Z.; Najeeb, S.; Shahab, S.; Zafar, M.S. Oral antimicrobial peptides: Types and role in the oral cavity. Saudi Pharm. J. 2016, 24, 515-524. [CrossRef]

24. Emami, E.; Kabawat, M.; Rompre, P.H.; Feine, J.S. Linking evidence to treatment for denture stomatitis: A meta-analysis of randomized controlled trials. J. Dent. 2014, 42, 99-106. [CrossRef] [PubMed]

25. Yarborough, A.; Cooper, L.; Duqum, I.; Mendonça, G.; McGraw, K.; Stoner, L. Evidence regarding the treatment of denture stomatitis. J. Prosthodont. 2016, 25, 288-301. [CrossRef] [PubMed]

26. Al-Shayyab, M.H.; Abu-Hammad, O.A.; Al-Omiri, M.K.; Dar-Odeh, N.S. Antifungal prescribing pattern and attitude towards the treatment of oral candidiasis among dentists in Jordan. Int. Dent. J. 2015, 65, 216-226. [CrossRef]

27. Lyu, X.; Zhao, C.; Yan, Z.-M.; Hua, H. Efficacy of nystatin for the treatment of oral candidiasis: A systematic review and meta-analysis. Drug Des. Devel. Ther. 2016, 10, 1161. [CrossRef] [PubMed]

28. Martin-Mazuelos, E.; Aller, A.; Romero, M.; Armijo, A.R.; Gutierrez, M.; Bernal, S.; Montero, O. Response to fluconazole and itraconazole of Candida spp. in denture stomatitis. Mycoses 1997, 40, 283-289. [CrossRef]

29. Falah-Tafti, A.; Jafari, A.A.; Lotfi-Kamran, M.H.; Fallahzadeh, H.; Hayan, R.S. A comparison of the efficacy of nystatin and fluconazole incorporated into tissue conditioner on the in vitro attachment and colonization of Candida albicans. Dent. Res. J. 2010, 7, 18-22.

30. Alcântara, C.S.; de Macêdo, A.F.; Gurgel, B.C.; Jorge, J.H.; Neppelenbroek, K.H.; Urban, V.M. Peel bond strength of resilient liner modified by the addition of antimicrobial agents to denture base acrylic resin. J. Appl. Oral Sci. 2012, 20, 607-612. [CrossRef]

31. Hashem, M.I. Advances in soft denture liners: An update. J. Contemp. Dent. Pract. 2015, 16, 314-318. [PubMed]

32. Sahebjamee, M.; Shabestari, S.B.; Asadi, G.; Neishabouri, K. Predisposing factors associated with denture induced stomatitis in complete denture wearers. J. Dent. 2019, 11, 35-39.

33. Leite, D.P.; Piva, M.R.; Martins-Filho, P.R.S. Identification of Candida species in patients with denture stomatitis and evaluation of susceptibility to miconazole and photodynamic therapy. Rev. Odontol. UNESP 2015, 44, 12-17. [CrossRef]

34. Acosta-Torres, L.S.; Mendieta, I.; Nuñez-Anita, R.E.; Cajero-Juárez, M.; Castaño, V.M. Cytocompatible antifungal acrylic resin containing silver nanoparticles for dentures. Int. J. Nanomed. 2012, 7, 4777.

35. Yamamoto, D.; Shinohara, Y.; Nagadome, H.; Terada, Y. Development of tissue conditioner capable of binding with anti-microbial protein lactoferrin. J. Prosthodont. Res. 2009, 53, 136-141. [CrossRef]

36. Samaranayake, L.P.; Ferguson, M.M. Delivery of antifungal agents to the oral cavity. Adv. Drug Deliv. Rev. 1994, 13, 161-179. [CrossRef]

37. Akiba, N.; Hayakawa, I.; Keh, E.-S.; Watanabe, A. Antifungal effects of a tissue conditioner coating agent with TiO 2 photocatalyst. J. Med. Dent. Sci. 2005, 52, 223-227.

38. Kumar, N.; Kumari, A.; Priyadarshi, V.; Kumar, A.; Prasad, R.S.; Kumar, B. A comparative efficacy of Nystatin and Fluconazole incorporated into tissue conditioner as drug delivery method for Denture stomatitis. J. Adv. Med. Dent. Sci. Res. 2020, 8, 159-162.

39. Webb, B.; Thomas, C.; Willcox, M.; Harty, D.; Knox, K. Candida-associated denture stomatitis. Aetiology and management: A review: Part1. Factors influencing distribution of candida species in the oral cavity. Aust. Dent. J. 1998, 43, 45-50. [CrossRef]

40. Chow, C.; Matear, D.; Lawrence, H. Efficacy of antifungal agents in tissue conditioners in treating candidiasis. Gerodontology 1999, 16, 110-118. [CrossRef]

41. Geerts, G.; Stuhlinger, M.; Basson, N. Effect of an antifungal denture liner on the saliva yeast count in patients with denture stomatitis: A pilot study. J. Oral Rehabil. 2008, 35, 664-669. [CrossRef] [PubMed]

42. Julian, J.; Sunil, S.; Baby, G.G. Efficacy of tissue conditioner acting as effective fungicidal drug delivery system-An invitro study. Oral Maxillofac. Pathol. J. 2010, 1, 10-15. 
43. Chopde, N.; Pharande, A.; Khade, M.N.; Khadtare, Y.R.; Shah, S.S.; Apratim, A. In vitro antifungal activity of two tissue conditioners combined with nystatin, miconazole and fluconazole against Candida albicans. J. Contemp. Dent. Pract. 2012, 13, 695-698. [PubMed]

44. Fallah-Tafti, A.; Jafari, A.; Mirzaeiipoorm, L.; Ashoori, H. Stability and duration of antifungal effects of nystatin and fluconazole mixed with a tissue conditioner on colonization of Candida albicans (in vitro). Res. Dent. Sci. 2014, 11, 21-26.

45. Bueno, M.; Urban, V.; Barbério, G.; Da Silva, W.; Porto, V.; Pinto, L.; Neppelenbroek, K. Effect of antimicrobial agents incorporated into resilient denture relines on the Candida albicans biofilm. Oral Dis. 2015, 21, 57-65. [CrossRef] [PubMed]

46. Barua, D.R.; Basavanna, J.M.; Varghese, R.K. Efficacy of neem extract and three antimicrobial agents incorporated into tissue conditioner in inhibiting the growth of C. albicans and S. mutans. J. Clin. Diagn. 2017, 11, ZC97-ZC101. [CrossRef]

47. Hotta, J.; Garlet, G.P.; Cestari, T.M.; Lima, J.F.M.; Porto, V.C.; Urban, V.M.; Neppelenbroek, K.H. In vivo biocompatibility of an interim denture resilient liner containing antifungal drugs. J. Prosthet. Dent. 2019, 121, 135-142. [CrossRef]

48. Radnai, M.; Whiley, R.; Friel, T.; Wright, P.S. Effect of antifungal gels incorporated into a tissue conditioning material on the growth of Candida albicans. Gerodontology 2010, 27, 292-296. [CrossRef]

49. de Souza, R.F.; Khiyani, M.F.; Chaves, C.A.; Feine, J.; Barbeau, J.; Fuentes, R.; Borie, E.; Crizostomo, L.C.; Silva-Lovato, C.H.; Rompre, P. Improving practice guidelines for the treatment of denture-related erythematous stomatitis: A study protocol for a randomized controlled trial. Trials 2017, 18, 211. [CrossRef]

50. Bakhshi, M.; Taheri, J.B.; Shabestari, S.B.; Tanik, A.; Pahlevan, R. Comparison of therapeutic effect of aqueous extract of garlic and nystatin mouthwash in denture stomatitis. Gerodontology 2012, 29, e680-e684. [CrossRef]

51. Ibraheem, E.M.A.; Dehis, W.M. Effect of tissue conditioner combined with nystatin on growth of candida albicans in complete denture wearers. Egypt. Dent. J. 2016, 62, 393-398. [CrossRef]

52. Schneid, T.R. An in vitro analysis of a sustained release system for the treatment of denture stomatitis. Spec. Care Dentist. 1992, 12, 245-250. [CrossRef] [PubMed]

53. Urban, V.M.; De Souza, R.F.; Arrais, C.A.G.; Borsato, K.T.; Vaz, L.G. Effect of the association of nystatin with a tissue conditioner on its ultimate tensile strength. J. Prosthodont. 2006, 15, 295-299. [CrossRef] [PubMed]

54. Urban, V.M.; Seó, R.S.; Giannini, M.; Arrais, C.A.G. Superficial distribution and identification of antifungal/antimicrobial agents on a modified tissue conditioner by SEM-EDS microanalysis: A preliminary study. J. Prosthodont. 2009, 18, 603-610. [CrossRef] [PubMed]

55. Urban, V.M.; Lima, T.F.; Bueno, M.G.; Giannini, M.; Filho, J.N.A.; de Almeida, A.L.P.; Neppelenbroek, K.H. Effect of the addition of antimicrobial agents on Shore A hardness and roughness of soft lining materials. J. Prosthodont. 2015, 24, 207-214. [CrossRef] [PubMed]

56. Lima, J.F.; Maciel, J.G.; Arrais, C.A.; Porto, V.C.; Urban, V.M.; Neppelenbroek, K.H. Effect of incorporating antifungals on the water sorption and solubility of interim resilient liners for denture base relining. J. Prosthet. Dent. 2016, 115, 611-616. [CrossRef]

57. Lima, J.F.M.; Maciel, J.G.; Hotta, J.; Vizoto, A.C.P.; Honório, H.M.; Urban, V.M.; Neppelenbroek, K.H. Porosity of temporary denture soft liners containing antifungal agents. J. Appl. Oral Sci. 2016, 24, 453-461. [CrossRef]

58. Homsiang, W.; Kamonkhantikul, K.; Arksornnukit, M.; Takahashi, H. Effect of zinc oxide nanoparticles incorporated into tissue conditioner on antifungal, physical, and mechanical properties. Dent. Mater. J. 2020, 2020-2095. [CrossRef]

59. Page, M.J.; Moher, D.; Bossuyt, P.; Boutron, I.; Hoffmann, T.; Mulrow, C.; Shamseer, L.; Tetzlaff, J.; Akl, E.; Brennan, S.E.; et al. PRISMA 2020 explanation and elaboration: Updated guidance and exemplars for reporting systematic reviews. MetaArXiv 2020. [CrossRef]

60. McHugh, M.L. Interrater reliability: The kappa statistic. Biochem. Med. Biochem. Med. 2012, 22, 276-282. [CrossRef]

61. Sterne, J.A.; Hernán, M.A.; Reeves, B.C.; Savović, J.; Berkman, N.D.; Viswanathan, M.; Henry, D.; Altman, D.G.; Ansari, M.T.; Boutron, I.; et al. ROBINS-I: A tool for assessing risk of bias in non-randomised studies of interventions. Br. Med. J. 2016, 355, i4919. [CrossRef] [PubMed]

62. Hooijmans, C.R.; Rovers, M.M.; De Vries, R.B.; Leenaars, M.; Ritskes-Hoitinga, M.; Langendam, M.W. SYRCLE's risk of bias tool for animal studies. BMC Med. Res. Methodol. 2014, 14, 43. [CrossRef]

63. Douglas, W.H.; Clarke, D. Physical and mechanical properties of nystatin-containing denture liners. J. Prosthet. Dent. 1975, 34, 428-434. [CrossRef]

64. Barkvoll, P.; Attramadal, A. Effect of nystatin and chlorhexidine digluconate on Candida albicans. Oral Surg. Oral Med. Oral Pathol. 1989, 67, 279-281. [CrossRef]

65. El-Charkawi, H.; El-Said, E.; Safouh, H.; El-Raghi, N. Effect of addition antimicrobial agents to denture reliners. Egypt. Dent. J. 1994, 40, 785-790.

66. Truhlar, M.R.; Shay, K.; Sohnle, P. Use of a new assay technique for quantification of antifungal activity of nystatin incorporated in denture liners. J. Prosthet. Dent. 1994, 71, 517-524. [CrossRef]

67. Blomgren, J.; Berggren, U.; Jontell, M. Fluconazole versus nystatin in the treatment of oral candidosis. Acta Odontol. Scand. 1998, 56, 202-205. [CrossRef]

68. Ellepola, A.N.; Samaranayake, L. Adhesion of oral Candida albicans isolates to denture acrylic following limited exposure to antifungal agents. Arch. Oral Biol. 1998, 43, 999-1007. [CrossRef]

69. AL-Dwairi, Z.N.; AL-Quran, F.A.; AL-Omari, O.Y. The effect of antifungal agents on surface properties of poly (methyl methacrylate) and its relation to adherence of Candida albicans. J. Prosthodont. Res. 2012, 56, 272-280. [CrossRef] 
70. Sanchez-Aliaga, A.; Pellissari, C.V.G.; Arrais, C.A.G.; Michel, M.D.; Neppelenbroek, K.H.; Urban, V.M. Peel bond strength of soft lining materials with antifungal to a denture base acrylic resin. Dent. Mater. J. 2016, 35, 194-203. [CrossRef]

71. Atai, Z.; Atai, M.; Amini, J. In vivo study of antifungal effects of low-molecular-weight chitosan against Candida albicans. J. Oral Sci. 2017, 59, 425-430. [CrossRef] [PubMed]

72. Bueno, M.G.; de Sousa, E.J.B.; Hotta, J.; Porto, V.C.; Urban, V.M.; Neppelenbroek, K.H. Surface properties of temporary soft liners modified by minimum inhibitory concentrations of antifungals. Braz. Dent. J. 2017, 28, 158-164. [CrossRef] [PubMed]

73. Garaicoa, J.L.; Fischer, C.L.; Bates, A.M.; Holloway, J.; Avila-Ortiz, G.; Guthmiller, J.M.; Johnson, G.K.; Stanford, C.; Brogden, K.A. Promise of combining antifungal agents in denture adhesives to fight Candida species infections. J. Prosthodont. 2018, $27,755-762$. [CrossRef] [PubMed]

74. Neppelenbroek, K.H.; Lima, J.F.M.; Hotta, J.; Galitesi, L.L.; Almeida, A.L.P.F.; Urban, V.M. Effect of incorporation of antifungal agents on the ultimate tensile strength of temporary soft denture liners. J. Prosthodont. 2018, 27, 177-181. [CrossRef] [PubMed]

75. Bassi, R.C.; Boriollo, M.F. Amphotericin B, fluconazole, and nystatin as development inhibitors of Candida albicans biofilms on a dental prosthesis reline material: Analytical models in vitro. J. Prosthet. Dent. 2020. [CrossRef]

76. Thomas, C.; Nutt, G. The in vitro fungicidal properties of Visco-gel, alone and combined with nystatin and amphotericin B. J. Oral Rehabil. 1978, 5, 167-172. [CrossRef]

77. Kim, H.J.; Son, J.S.; Kwon, T.Y. Antifungal Effect of a Dental Tissue Conditioner Containing Nystatin-Loaded Alginate Microparticles. J. Nanosci. Nanotechnol. 2018, 18, 848-852. [CrossRef]

78. Douglas, W.H.; Walker, D.M. Nystatin in denture liners-an alternative treatment of denture stomatitis. Br. Dent. J. 1973, 135, 55-59. [CrossRef]

79. Bergendal, T.; Isacsson, G. Effect of nystatin in the treatment of denture stomatitis. Scand. J. Dent. Res. 1980, 88, 446-454. [CrossRef]

80. Alrabiah, M.; Alsahhaf, A.; Alofi, R.S.; Al-Aali, K.A.; Abduljabbar, T.; Vohra, F. Efficacy of photodynamic therapy versus local nystatin in the treatment of denture stomatitis: A randomized clinical study. Photodiagn. Photodyn. Ther. 2019, 28, 98-101. [CrossRef]

81. Afroozi, B.; Zomorodian, K.; Lavaee, F.; Shahrabadi, Z.Z.; Mardani, M. Comparison of the efficacy of indocyanine green-mediated photodynamic therapy and nystatin therapy in treatment of denture stomatitis. Photodiagn. Photodyn. Ther. 2019, 27, 193-197. [CrossRef] [PubMed]

82. Gonoudi, E.; Rezai, M.; Farrokhnia, T.; Goudarzi, M.; Sima, A. Comparison of Antifungal Efficacy of Zataria multiflora and Nystatin for Treatment of Denture Stomatitis: A Randomized Clinical Trial. J. Dent. 2020. [CrossRef]

83. Omran, S.M.; Dastjerdi, M.R.; Zuashkiani, M.; Moqarabzadeh, V.; Taghizadeh-Armaki, M. In vitro antifungal susceptibility of candida species isolated from Iranian patients with denture stomatitis. BioMed Res. Int. 2018, 2018, 1-6. [CrossRef] [PubMed]

84. Nairn, R. Nystatin and amphotericin B in the treatment of denture-related candidiasis. Oral Surg. Oral Med. Oral Pathol. 1975, 40, 68-75. [CrossRef]

85. Bergman, B.; Carlsson, G.E.; Ericson, S. Effect of differences in habitual use of complete dentures on underlying tissues. Eur. J. Oral Sci. 1971, 79, 449-460. [CrossRef] [PubMed]

86. Budtz-Jørgenskn, E.; Bertram, U. Denture stomatitis: II. The effect of antifungal and prosthetic treatment. Acta Odontol. Scand. 1970, 28, 283-304. [CrossRef] [PubMed]

87. Pindborg, J.J. Atlas of Diseases of the Oral Mucosa, 2nd ed.; Munksgaard: Copenhagen, Denmark, 1980.

88. Woods, R.A. Nystatin-resistant mutants of yeast: Alterations in sterol content. J. Bacteriol. 1971, 108, 69-73. [CrossRef]

89. Bard, M. Biochemical and genetic aspects of nystatin resistance in Saccharomyces cerevisiae. J. Bacteriol. 1972, $111,649-657$. [CrossRef]

90. Mohamadi, J.; Motaghi, M. Anti-fungal resistance in candida isolated from oral and diaper rash candidiasis in neonates. Bioinformation 2014, 10, 667. [CrossRef]

91. Iqbal, Z.; Zafar, M. Role of antifungal medicaments added to tissue conditioners: A systematic review. J. Prosthodont. Res. 2016, 60, 231-239. [CrossRef]

92. Khurshid, Z.; Zafar, M.; Qasim, S.; Shahab, S.; Naseem, M.; AbuReqaiba, A. Advances in nanotechnology for restorative dentistry. Materials 2015, 8, 717-731. [CrossRef] [PubMed] 